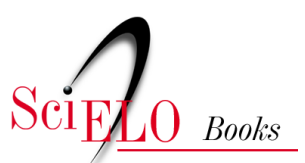

\title{
Bricolagem alimentar
}

\author{
Maria Cláudia da Veiga Soares Carvalho
}

\section{SciELO Books / SciELO Livros / SciELO Libros}

CARVALHO, M. C. V. S. Bricolagem alimentar. In: Bricolagem alimentar nos estilos naturais [online]. Rio de Janeiro: EDUERJ, 2013, pp. 65-87. ISBN: 978-65-88808-07-8.

https://doi.org/10.7476/9786588808078.0006.

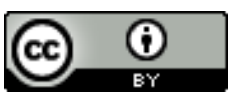

All the contents of this work, except where otherwise noted, is licensed under a Creative Commons Attribution 4.0 International license.

Todo o conteúdo deste trabalho, exceto quando houver ressalva, é publicado sob a licença Creative Commons Atribição 4.0.

Todo el contenido de esta obra, excepto donde se indique lo contrario, está bajo licencia de la licencia Creative Commons Reconocimento 4.0. 


\section{Bricolagem alimentar}

\section{O bricoleur segue uma ordenação primária}

A conceituação de bricolagem alimentar é uma reconstrução do conceito de bricolagem de Lévi-Strauss no campo da alimentação. Além de Lévi-Strauss, Ricoeur e Canevacci foram fundamentais nessa conceituação. A estrutura básica da bricolagem é a de um novo arranjo simbólico com significados "usados" - uma nova ordem adaptada que oscila entre confusão e criação antes de ser considerada propriamente ordenada e organizada em seu habitat. Lévi-Strauss faz uma aproximação da bricolagem com o pensamento selvagem por meio de uma espécie de "tesouro de ideias", a reflexão mítica:

O bricoleur está apto a executar grande número de tarefas diferentes; mas, diferentemente do engenheiro, ele não subordina cada uma delas à obtenção de matérias-primas e de ferramentas, concebidas e procuradas na medida de seu projeto: seu universo instrumental é fechado e a regra de seu jogo é a de arranjar-se sempre com os meios-limites, isto é, um conjunto, continuamente restrito, de utensílios e materiais, heteróclitos, além do 
mais porque a composição do conjunto não está em relação com o projeto do momento, nem, aliás, com qualquer projeto particular, mas é o resultado contingente de todas as ocasiões que se apresentaram para renovar e enriquecer o estoque, ou para conservá-lo, com resíduos de construções e destruições anteriores (1976, p. 38).

Para Lévi-Strauss, bricolagem é uma "ciência primária antes que primitiva" (p. 29) em que o pensamento selvagem também expressa uma exigência de ordenação: "Toda classificação é superior ao caos" (p. 36) e busca, assim como a ciência, saber e determinar. Nesse sentido, em lugar de "opor magia e ciência, melhor seria colocá-las em paralelo, como duas formas de conhecimento, desiguais quanto aos resultados teóricos e práticos [...]” (p. 34). A principal diferença é que a magia não visa a um determinismo global. Esse autor cita exemplos de classificação no mundo indígena em que a bricolagem é motivada pela curiosidade e se realiza no contato íntimo e afetivo dos indígenas com a natureza, em que plantas e animais assumem papéis específicos nas narrativas mitológicas.

$\mathrm{O}$ pensamento selvagem possui extrema familiaridade e afetividade com o meio biológico e dedica a este uma atenção apaixonada por intermédio de um contato íntimo com a natureza, percebendo sutilezas, atribuindo significados e classificando muitas espécies de planta de modo próprio. Por exemplo, se as flores são para nós parte das plantas que devem ser colhidas para embelezar e perfumar um ambiente, para os índios Omaha são valiosas como raízes sagradas colhidas para banhos terapêuticos.

A exigência de significação é uma necessidade humana, e o fato de não a compreendermos inteira ou conscientemente não a invalida como organização. A bricolagem é um processo de ordenação em construção, um modo de atribuir sentidos e significados, legitimados ou legitimando-os na prática, num contexto so- 
cial. Representa um modus operandi em que os mitos são usados como operadores de um inventário simbólico que reproduz uma estrutura social. Para analisá-los, Lévi-Strauss utiliza os conceitos, diferentemente dos perceptos, relacionados à situação concreta, na experiência, pois aqueles representam um modo abstraído de compreensão no ato reflexivo de pensar a experiência. Na reflexão mítica, os conceitos, assim como os perceptos, embora diferentemente, são inerentes à vivência, do mesmo modo que os signos - que fazem na mediação com a imagem uma organização de significado e significante - são "um laço entre a imagem e o conceito, os quais na união assim realizada representam, respectivamente, os papéis de significante e significado" (p. 39).

O signo e o conceito se referem a outra coisa que não a si próprios, diferentemente da imagem que não tem ideia, embora coabite com uma ideia no signo. O signo, para Lévi-Strauss, depende de uma imagem "it adresses somebody" (p. 41). No entanto, o signo e o conceito operam de modos diferentes. Enquanto os conceitos são ilimitados, os signos têm uma potencialidade limitada para representação. Um cientista opera por meio de conceitos, transparentes à realidade, e o bricoleur, por intermédio de signos, que expressam uma opacidade incorporada à realidade.

Nas narrativas míticas, embora seja permitido em qualquer momento reconfigurar o signo, assim como transformar as próprias narrativas no ato de narrar, o signo não está livre de história, de ter um passado na realidade em que vive. "As probabilidades permanecem sempre limitadas pela história particular de cada peça e pelo que nela subsiste de predeterminado, devido ao uso original [...]" (p. 40). Se ele é um signo, está ou já esteve, de algum modo, associado a uma imagem construída pelo homem. Sua condição de existência é o próprio olhar desse homem quando lança uma luz sobre a imagem e constrói o signo. Dito de outro modo, o uso do signo na prática está pré-constrangido, semideterminado, impregnado com alguma história porque se constitui 
como um fragmento simbólico localizado no tempo e no espaço social que habita.

No entanto, a existência de um signo não depende de nossa consciência; um signo pode ser reconstruído na prática sem sequer termos consciência. Sua transformação também pode ocorrer sem os agentes saberem que o estão transformando. Muitas vezes, agimos como se um signo fosse totalmente novo, por exemplo, no ato de narrar, sem nos darmos conta de que ele nasce na imanência da junção de uma imagem com uma ideia, o que se diferencia da construção do cientista, que antecipa uma mensagem arrancada do mundo com uma pergunta que não tenha sido feita anteriormente.

$\mathrm{Na}$ narrativa mítica de Gaia, os elementos imaginários são (re)traduzidos em signos e orientam o estilo natural. $\mathrm{O}$ planeta Terra está associado a essa deusa grega num arranjo curioso de elementos, sem compromisso com uma verdade científica. Segundo Lévi-Strauss, bricolagem é um termo ligado a uma ação incidental, algo que não era planejado nem previsto para acontecer: um fazer à mão com aquilo que se tem à mão. Uma reconstrução com combinações criativas e um equilíbrio precário entre estrutura e acontecimento, necessidade e contingência, "constantemente ameaçado pelas trações que se exercem, num sentido e noutro, conforme as flutuações da moda, do estilo e das condiçôes sociais gerais" (p. 57). O ponto de partida é inusitado.

\section{A bricolagem é consensual}

Para Paul Ricoeur, o pensamento selvagem é o da ordem, mas é um pensamento que não se pensa, "uma explicação em primeiro lugar limitada; em seguida, pouco a pouco ampliada, seguindo o fio condutor dos próprios problemas" (1978, p. 30). Nessa perspectiva, o autor articula duas maneiras de compreender o mundo: a antropologia estrutural na dimensão da ciência, e a 
hermenêutica na da filosofia. Mergulha na linguística e na comunicação para com a hermenêutica chegar a um sentido suspenso no símbolo, entre o abstraído e o concreto.

Operacionaliza o conceito de bricolagem no ato de interpretar os princípios de manifestações linguísticas e comunicativas em geral. Onde houver linguagem, aplicar-se-á a interpretação e vice-versa; tudo que é objeto de interpretação é também uma forma de linguagem, pois são as diferenças de som e sentido, e as relações de uns com os outros, que constituem o sistema dos signos de uma língua. Uma linguagem deve ser compreendida como fruto de uma experiência que teve um sentido e se estruturou formando um sistema. Entende-se que cada signo seja arbitrário enquanto uma relação isolada de um sentido e de um som, mas que todos os signos de uma língua formem um sistema consensuado socialmente.

Ricoeur pensa o caráter comunicativo na constituição de um signo como forma de conferir poder ao agente quando este se apropria de um signo na comunicação, o que implica um poder, distinto de uma sucessão regular. A possibilidade da ação concreta de comunicação está naquilo que o agente toma para si, conquista, pois o que lhe é de direito por uma sucessão regular, ainda que legitimado pela sociedade em que vive, nem sempre ele toma como seu. Assim, para Ricoeur, a comunicação é uma ação capaz de expressar algumas intimidades do agente com os signos por ele apropriados e tornados seus no contexto social. Atribuindo um caráter de sistema consensuado socialmente, da mesma forma como opera um sistema linguístico sobre a alimentação, observamos que algumas vezes um agente social não se apropria dos sentidos do estilo natural e atribui outro significado ao comer que não o de um naturista. Esse seria um comer destituído dos significados e sentidos consensuais, um comer que não identifica esse sujeito como naturista. 
Canevacci reforça esse aspecto ativo no sujeito da comunicação com a concepção de que a comunicação é negociada, “o destinatário não é mais um recipiente passivo, ponto final do fluxo comunicativo, mas um sujeito ativo, um intérprete que negocia os significados" (2001, p. 245), embora uma negociação não tenha pretensão libertária para a formação de um "quilombo" simbólico, como ocorre no sincretismo. "A bricolagem joga com um número limitado de cartas. No sincretismo, elas são infinitas" (1996, p. 31). Seu habitat é a realidade concreta e o senso comum, em que as concepções muitas vezes se apresentam com uma pobreza conceitual.

O bricoleur negocia significados para que um consenso se estabeleça, apropriando-se com intimidade de um pensamento selvagem de fragmentos simbólicos na construção de unidades de sentido. $\mathrm{O}$ consenso não busca somente reorganizar os signos para dar sentido à vida; às vezes pode representar uma denúncia contra a falta de sentido. Nas palavras de Lévi-Strauss,

o pensamento mítico não é somente o prisioneiro de acontecimentos e de experiências que ordena e reordena incansavelmente para lhes descobrir um sentido; é também libertador, pelo protesto feito contra a falta de sentido, com que a ciência estava, a princípio, resignada a transigir (1976, p. 43).

Dessa forma, bricolagem é um conceito propício à diversidade cultural da sociedade contemporânea, e bricolagem alimentar, um conceito que reinterpreta significados que ora se reproduzem com aparência caótica e criativa nas práticas de alimentação. Segundo Canevacci, bricolagem seria um "modelo atual de difusão das ideologias [que] poderia ser definido como um tipo ventríloquo, no sentido de que a ideia nasce, é emitida, reproduzida e comunicada diretamente pelas coisas, pelo produto-mercadoria, pelo gadget” (2001, p. 244) - seria, assim, uma ressignificação 
contínua que atribui significados aos alimentos no imaginário social, fazendo acordos simbólicos para chegar a um consenso, que, com equilíbrio precário, ordena e reordena a experiência.

Appadurai (2003) reafirma esse caráter de negociação na complexidade de um sistema de significação compreendendo a imaginação como prática social. Segundo ele, a imaginação já seria um espaço de contestação, negociações e construção que incorpora o global das práticas cotidianas. Um imaginário que leva o sujeito à ação não mais como uma inocente fantasia, fuga da realidade ou contemplação passiva, mas que pode tomar parte na produção dos assuntos locais. A imaginação no sentido de prática social é componente de uma nova forma de ordenação global.

Para compreendermos as negociações simbólicas presentes no imaginário do natural, voltamos um pouco aos devaneios iluministas, quando o romantismo acirrou a incorporação da sensibilidade e da imaginação. Segundo Campbell, tratava-se aqui de um imaginário orientado pelo romantismo do século XVIII, diferente do rousseaniano, no sentido de que estaria mais centrado no combate ao artificial e tecnológico, de forma inerente ao consumismo moderno, estivesse o consumo incorporado de um sentido valorizado de criação, estivesse ele com um sentido desvalorizado de alienação.

O sentir e o imaginar se articulam nas práticas de alimentação quando refletem ou se constroem no espaço social como ideias de todos, sonhos coletivos. As pessoas degustam e consomem os alimentos juntamente a um consenso simbólico de um imaginário coletivo. Como diz a música de Raul Seixas, "um sonho que se sonha só é só um sonho que se sonha só, mas um sonho que se sonha junto é realidade". Um sonho pode ser socializado nos estilos de vida e incorporado a eles para ser vivenciado na coletividade. Por exemplo, o arquétipo de amor juvenil de Romeu e Julieta em Shakespeare seria descabido nas práticas amorosas da antiguidade, 
ainda que intensos amores tenham sido alvo de tragédias, pois o palco dessa tragédia é a modernidade. Segundo Engels,

em toda antiguidade, são os pais que combinam os casamentos, em vez dos interessados; e estes conformam-se, tranquilamente. $\mathrm{O}$ pouco amor conjugal que a antiguidade conhece não é uma inclinação subjetiva, e sim, mais concretamente, um dever objetivo; não é a base, e sim o complemento do matrimônio. $\mathrm{O}$ amor, no sentido moderno da palavra, somente se apresenta na antiguidade fora da sociedade oficial (1964, p. 63).

De acordo com Campbell, o culto ao amor romântico floresceu mais intensamente na classe média: "Ela, e não a nobreza, funcionava como formadora do gosto da sociedade, e assim fazendo, dava expressão a valores e atitudes muito diferentes dos que há muito caracterizavam o estilo de vida da elite inglesa" (2001, pp. 53-4). Um comportamento romanticamente motivado está associado a uma ética especificamente burguesa cujas crenças e valores não diziam respeito somente à intensa preocupação moral e religiosa dos puritanos, mas também a uma indulgência com o consumo de luxo e a um favorecimento da ficção na literatura. A tendência histórica da classe média a dar nascimento a projetos originais e criativos propiciava a ela mais disposição para o culto ao amor porque lhe fornecia mais familiaridade com o devaneio romântico.

$\mathrm{O}$ amor, nesse sentido social e cultural de sonho coletivo, remete a um ethos romântico que alimenta o natural. $\mathrm{O}$ consumo, nos termos de Campbell, se aproxima do comer nas práticas de alimentação e representa apetites, respostas dadas a uma necessidade construída no imaginário. Respostas que refletem uma preferência e estão em continuidade com uma experiência anterior, tenham sido satisfeitas ou não. $\mathrm{O}$ consumo é um ato social contínuo em nossa cultura, que traz em si uma possibilidade futura 
de realização, em que tanto a saciedade quanto a necessidade são ao mesmo tempo particulares e sociais, num corpo socialmente informado pelos sonhos coletivos.

Nesse sentido, o consumo da classe média não é tão materialista. O preço da refeição não é o único e nem sempre o mais importante elemento do devaneio que estimula o consumo. Numa alimentação natural, o custo pode representar uma condição para o acesso à refeição, mas nem sempre representa a motivação principal. Uma das veganas com quem convivi nesse período, antes de ser vegana, tinha uma vida de classe média alta junto à sua família; quando fala sobre sua transformação, o faz de modo romântico. Ela se casou e saiu da casa dos pais, na beira da Praia de Ipanema, para viver com o marido em Vargem Grande, numa casinha sem conforto, numa matinha de um futuro condomínio, com o sonho de "um amor e uma cabana". Segundo ela, as dificuldades eram muitas, mas havia também o sentimento de amor e solidariedade entre os que ali habitavam - uma vizinha passou a ajudá-la na alimentação por ocasião do nascimento do filho (da mulher que deixou Ipanema), ensinando-a a fazer pão. Com o tempo, ela foi se tornando vegetariana, começou a fazer pão integral para vender e depois abriu uma pequena loja perto de sua moradia.

Vários entrevistados relataram mudança de moradia, de uma cidade pequena para o Rio ou do Rio para outras cidades, motivados por um sonho de liberdade e amor. A imagem juvenil de colocar "o pé na estrada" não representou um plano para "subir na vida", voltado para melhores condiçóes socioeconômicas. Um deles saiu da casa dos pais no Rio com 19 anos, uma "calça vermelha, mochila vazia, camisa estampada, cabelo grande, estava pirado". Vivia como os hippies nas praças e foi de carona em carona pelas estradas até chegar à Bahia. Em Salvador, fazia artesanato para sobreviver e, com uma vida em comum com amigos, logo começou a preparar comida para vender. Colocar o pé na estrada fazia parte do desejo de alcançar uma liberdade pessoal e 
sair da tensão que lhe causava ver o mundo em deterioração. Um sonho de uma geração dos anos 1960 capturado no enredo do filme escrito por Peter Fonda, Dennis Hopper e Terry Southern, Easy rider.

O ethos romântico desenvolve uma disposição para a resistência que gera nas práticas naturistas uma ressignificação de alimentos para novas sensibilidades, preferências, gostos e apetites, o que se constrói em oposição ao fast food. As novas sensações envolvem certa ojeriza à ingestão de carnes de origem animal, especialmente a vermelha: "Sempre respeitei meu desejo, enquanto salivei com a carne... [comia], hoje não como, sinto enjoo com o cheiro da carne". O naturista é mais flexível do que o vegano quanto à carne, mas em geral ambos atribuem sabedoria a algumas sensações: compreendem que, quando o corpo necessita de algum nutriente, sabiamente saliva pelo alimento que pode suprir essa carência. Um arranjo simbólico que, negociado com a noção moderna de deficiência de micronutrientes, orienta uma construção social do gosto: a "salivação [é] pelo alimento de que o corpo necessita”.

O gosto, articulado à necessidade, é incorporado de modo consensual no contexto de significação do natural. Para os veganos, os alimentos animais fazem mal para o homem; portanto, o corpo não necessita deles e não vai salivar por eles. No entanto, a carência de vitamina B12 (cobalamina), ainda que consensualmente aceita como provável entre os veganos, não gera apetite, pois os alimentos que são fonte dela são predominantemente de origem animal, interditados. Há certo interesse em repô-la, mas, como têm consciência que ingeri-la oralmente não seria eficaz, alguns complementam a baixa ingestão de B12 na dieta com aplicações intramusculares, numa prática que registra um hibridismo do estilo vegan com a medicalização.

$\mathrm{Na}$ bricolagem alimentar, todos os significados podem ser negociados de modo aparentemente caótico antes que uma deci- 
são em consenso seja tomada: "O desejo comum de ser atraente para o sexo oposto, por exemplo, pode ser usado, desse modo, para ajudar a vender qualquer coisa, desde creme contra manchas ou cigarros até aperitivos, [pois] são os significados simbólicos que se acham vinculados aos produtos" (Campbell, 2001, p. 73). Um processo que não é irracional, nem sem sentido e fora do controle, como acusam alguns. Nem pode ser encarado como repreensível à natureza humana, pois, embora sem necessariamente termos consciência ou agirmos por vontade própria, a associação de imagens e sensaçôes é apreendida culturalmente nas trocas simbólicas.

Convivemos com uma mídia altamente capacitada para propagar princípios de associações entre produtos e sensaçôes agradáveis, sem que estejamos experimentando essas sensações, o que Campbell denomina devaneio, "considerado [uma] forma de atividade mental em que imagens futuras positivamente vividas são trazidas à mente" (p. 122). Os romances e filmes românticos reforçam a bondade e a sensibilidade dos heróis e das heroínas, raramente associados a imagens de repugnância ou desgraça. A dor e o sofrimento desses personagens nas tramas são um tipo de virtude, algo capaz de levá-los ao sucesso e ao final feliz.

Uma ética romântica acolhe a bricolagem alimentar no estilo natural porque é favorável tanto às ilusões e aos enganos quanto às sensações boas. As associações que envolvem o consumo estão em busca de um prazer imaginário, pois, ainda que nunca se tenha a sensação real de prazer, "a atividade fundamental do consumo não é a verdadeira seleção, compra ou uso dos produtos, mas a procura do prazer imaginativo a que a imagem do produto se presta" (p. 130). No consumismo contemporâneo, não é fundamental que o desejo seja insaciável, assim como não será impedimento se ele for saciável; fundamental é que ele seja altamente renovável simbólica e consensualmente. A cada novo produto, um novo romance, uma nova possibilidade de experimentar uma sensação boa; "o gosto, apreciado como o padrão característico 
das preferências de uma pessoa, é em grande parte uma função do devaneio" (p. 136).

Esse romantismo a que se refere Campbell se especializou, portanto, no devaneio constituinte de um imaginário que subsidia um consenso na bricolagem alimentar. Um romantismo que motiva a construção do velho com cara nova, cara lavada e natural, que pode seguir interesses ora revolucionários, ora comerciais, ora de modo ingênuo e alienado, ora ardiloso, dependendo do consenso que se estabeleça. Essa forma nova de cara lavada negocia passagens históricas, incorpora devaneios e cria sensações tensas em sua resistência ao estilo fast food e às novas tecnologias.

\section{Uma vida feliz que vem de fora}

Nunca fomos cathechisados. Fizemos foi Carnaval. O indio vestido de senador do Imperio. Fingindo de Pitt. Ou figurando nas operas de Alencar cheio de bons sentimentos portuguezes.

Oswald de Andrade

Oswald de Andrade tensiona a ideia de uma civilidade moderna industrial e sugere uma espécie de primitivismo com a deglutição do moderno civilizado, e cathechisado, em seu Manifesto antropofágico. Reivindica, com a imagem exagerada e alegórica do índio, elementos simbólicos de narrativas míticas contra uma herança da colonização europeia que desprestigia uma natureza brasileira, quando o faz com cara de europeu, fantasiado de senador do Império ou de Pitt. Curioso que a bricolagem, mesmo sem essa crítica erudita do modernismo brasileiro, evoca elementos míticos, primários, em arranjos simbólicos semelhantes a esse, que, embora mais mansos e inconscientes, se parecem com o que Canevacci chamaria de montagem sincrética de significados. Num ato simbólico, devoram "alguém para em seguida - após uma sadia deglutição reflexiva - regenerá-lo como algo totalmente 
diferente" (1996, p. 29). A ironia de Andrade com a imagem de um bárbaro tecnizado remete a um sentimento de resistência do naturista ao tecnologismo moderno. A bricolagem naturista deglute a crescente industrialização e urbanização dos grandes centros e as reinterpreta com princípios ecológicos numa espécie de Pindorama orientalizado.

O estilo natural segue um processo de orientalização do Ocidente, como falam Nogueira e Camargo Jr. (2007). Nasce no Brasil com a incorporação da macrobiótica na década de 1930 (Rapoport, 1994), numa espécie de deglutição do Oriente, que incorpora a filosofia difundida inicialmente por Georges Ohsawa e depois por Michio Kushi, seu discípulo, com a interpretação de um sistema binário yin/yang. Alimentos que nos eram estranhos foram trazidos do Oriente e incorporados como novas e boas opções nas práticas de alimentação, a exemplo de tubérculos, como a bardana, e algas. A culinária naturista incorporou nessa ocasião novos procedimentos técnicos, como a fermentação da soja na elaboração do tofu e do tempeh, a germinação de grãos e a preparação do glúten como substituto às carnes animais, impondo, de modo efetivo, adaptações em instituições públicas como a Vigilância Sanitária, que precisou construir novo referencial para analisar esses alimentos.

A culinária naturista expressa múltiplas culinárias numa ressignificação contínua que tem se estendido na vida social dos grandes centros como um jeito criativo e original de preparar e socializar a comida. Pude observar variedades como o sushi mineiro, feito com folha de couve e arroz integral, que resgata, numa concepção de caseiro e artesanal do estilo mineiro, o prestígio do alimento japonês; conseguindo prescindir do peixe, ele se distingue como vegan. A jacalhoada também é um bom exemplo de mistura de significados, troca simbólica. A jaca substitui o tradicional bacalhau na Semana Santa, deslocando o uso dessa fruta de preparações doces para um prato salgado. Uma ressignificação 
de fruta regional, nativa, de consumo e produção caseiros, meio desvalorizados, para um lugar de destaque de prato principal, de prestígio, equivalente ao bacalhau na época da Páscoa.

A substituição dos alimentos de origem animal pelos de origem vegetal em pratos típicos e emblemáticos da culinária é um recurso criativo e original da bricolagem nesses estilos. Assim, tanto os naturistas quanto os veganos apreciam pratos como a feijoada, o cozido, a paella, o arroz de carreteiro e o feijão tropeiro. Os velhos pratos com carnes são transformados em versões vegetarianas sem perder seu caráter de originalidade, de típico, numa variante criativa que incorpora ecologia e sustentabilidade.

O sentido de comer original do homem incorporado no estilo natural segue uma ideia de Natureza ancestral que se contrapõe a uma civilidade moderna dos grandes centros. Corresponde a um novo estilo de vida, feliz, que se organiza a partir de uma concepção de ruralidade feliz. Segundo Montanari, essa concepção tem suas raízes nos séculos XII e XIII com a "oposição de modelos alimentares, destinada a ter vida longa na cultura europeia: a que separa o campo da cidade" (2003, p. 70). Hoje representa "uma renovada autoconsciência do mundo rural. Mas trata-se sempre de valores urbanos: o campo feliz é uma imagem urbana [...] somente uma sociedade muito rica pode permitir-se apreciar a pobreza" (pp. 199-200).

Os sentidos de ancestral atribuídos a um mundo velho são os de retorno ao homem que não foi cathechisado, como fala Oswald de Andrade, um homem que vive sem complexos, sem loucura, sem prostituiçōes, sem penitenciárias. $\mathrm{Na}$ tese de Ossipow (1989), a vida no campo do vegetariano se aproxima do mito do bom selvagem, de Rousseau. No estilo natural, representa uma vida expressa por Zé Rodrix e Tavito, na voz de Elis Regina, pelo desejo de uma casa no campo, onde, "no silêncio das línguas cansadas", pudéssemos "compor muitos roques rurais". 
Conheci um casal na faixa dos quarenta, cinquenta anos que havia comprado um sítio no interior de Minas Gerais para construir uma vida no campo, com fontes de água limpa, cachoeira, mata e pastagens, onde a terra fosse boa para o plantio, "para plantar e colher com a mão a pimenta e o sal". O casal não se preocupava com a geração de renda no sítio; ambos estavam tranquilos em relação a isso, pois o plano era continuar trabalhando na cidade. Quando perguntados sobre seu sustento, mostravam confiança de que, indo à cidade regularmente, ganhariam o suficiente para viver; em momento algum foi considerada a possibilidade de abdicar disso. Embora um deles tivesse família numa cidade do interior, não pensavam em morar lá; o ponto central não era estar próximo da família. A imagem do campo feliz é a de uma Natureza ressacralizada.

$\mathrm{Na}$ perspectiva de uma classe média urbana carioca, a vida no campo inclui concretamente a cidade grande. O campo, isolado da cidade, impõe condiçôes de vida que muitas vezes inviabilizam o estilo natural. Essa prática envolve uma culinária com alimentos especializados. Até mesmo os alimentos orgânicos estão mais disponíveis nos grandes centros. É na cidade grande que se produz o imaginário da "roça". Um entrevistado que trabalhou na lavoura, embora valorizasse a vida no campo em seu universo simbólico, não tinha a intenção de retornar a ela. Disse já ter passado fome quando morava no campo e, quando voltou à cidade do Rio, estava em situação difícil; chegou a morar numa favela e passou tempos amargos que não gostaria de reviver. Agora, proprietário de uma pensão vegetariana, ele não conseguia imaginar a vida no campo como possibilidade concreta de viver bem, mas como sonho de ruralidade feliz.

Alguns locais próximos ao Rio de Janeiro se constituíram como possibilidades de vida no campo para os cariocas naturistas. O Brejal, localizado em Petrópolis, foi um desses lugares; abrigou sítios que formavam um núcleo que produzia alimentos orgânicos 
para a Coonatura e ainda hoje os produz para a feira orgânica da Glória. Vargem Grande foi outro lugar com aspecto rural.

Também aconteceram visitas esporádicas à cidade mineira de Gonçalves, onde foi igualmente possível perceber essa ideia de ruralidade feliz. Gonçalves é um pequeno município onde os paulistas da capital podem levar uma vida no campo sem prescindir inteiramente da cidade grande. Nessa região na Mantiqueira, naturistas vivem de suas massagens, terapias holísticas, da produção e venda de alimentos para turistas. Alguns fabricam doces em calda com preços só compatíveis com o poder aquisitivo de uma classe média que não a da própria cidade; tais doces trazem rótulos diferenciados, com informações nutricionais, e têm marketing jamais comparável ao dos costumeiramente produzidos em Gonçalves.

Um casal de moças foi representativo desse acordo simbólico entre o campo e a cidade. Uma trabalhava em Gonçalves, garantindo o espaço vida no campo, enquanto a outra ganhava dinheiro e fazia o marketing dos produtos alimentícios em São Paulo. Elas costumavam se encontrar nos fins de semana e feriados e comemoravam a opção por uma vida natural, que combinava São Paulo e campo. E, embora isso causasse um ressentimento por elas não estarem juntas durante toda a semana, garantia um sonho. A vida no campo, na perspectiva da classe média, é gestada nos grandes centros urbanos, não se desapega da alteridade cidade/campo. $\mathrm{O}$ estilo natural com o qual convivemos faz bricolagem alimentar em sua disposição para um projeto de vida no campo.

O naturismo realiza trocas simbólicas no processo de globalização como um avesso do fast food, fazendo oposição ao ritmo acelerado, apropriando-se de uma simbologia do ancestral como uma distinção social em seus modos de ser, sentir, pensar, imaginar e comer. Por um lado, contesta a industrialização e o processamento de alimentos da modernidade, construindo produtos alternativos do tipo caseiro e artesanal; por outro, submete-se ao mercado como mais uma opção para o comensal urbano, que, na 
ideia da variedade de oferta de produtos, reforça uma sensação de liberdade de escolha. O par de significação fast foodl natural referencia os significados no estilo natural.

A comida caseira é um símbolo da culinária naturista, que, na prática, emancipou-se da casa de família. Também é oferecida em restaurantes, com o mesmo significado de uma comida familiar. Caseiro é um alimento que se mantém no cardápio por um longo tempo sem grandes modificaçôes; alimento reconhecido como parte de práticas do cotidiano de geraçôes anteriores. Uma comida caseira é aquela que, além dos ingredientes, tem princípios de condimentação, procedimentos e técnicas próprios de um jogo simbólico que guarda regras sociais, morais, religiosas e higiênicas antigas. Uma culinária do tipo caseira tem vocação para a honestidade. São pratos de preparo simples, com poucas misturas de sabores nas refeições e um número reduzido de opções no cardápio. Os princípios de condimentação são modestos e despretensiosos. Usam-se muito o alho e a cebola como aquilo que garante a condição de prato bem temperado.

Comida artesanal também ressignifica o velho e se constrói como resistência a novas tecnologias, reproduzindo técnicas antigas e atribuindo valor ao trabalho manual. Moinhos, pilóes, moendas e rodas d'água, equipamentos associados às antigas fazendas, são imagens valorizadas e muito presentes nos restaurantes de comida artesanal e caseira. Uma entrevistada fez questão de reforçar que sua comida era toda preparada manualmente, como uma distinção de seu restaurante. A cozinha ficava à vista dos clientes para apreciação da preparação manual e pouco mecanizada dos pratos.

O sentido de resistência à civilização moderna, fordista e progressista é constituinte dessa concepção de artesanal e caseiro, resgata um significado de antigo, anterior à modernização, prestigiando-o, o que fica claro no protesto de Cascudo: 
Uma vitória da falsa economia sobre a normalidade da alimentação. Do 'progresso' contra a tradição valorizadora da refeição. Comer de pé, elegendo os pratos pela pressão de uma moda, é modalidade de pasto, indispensável, justo, mas não humano, não natural, não social. Anúncio de refeições em lata, pastilhas, comprimidos, cápsulas, água sintética, pílula contendo essência de café e chá, para findar é uma padronização do robô sobre o sapiens. [...] Deus me afaste desse 'progresso', antônimo de civilização (1973, p. 138).

$\mathrm{Na}$ prática, os significados são reinterpretados na bricolagem, e não faz sentido buscar a origem, mas, sim, uma relação no universo de significação, que, no caso do naturismo, inclui a tensão com a modernidade. As refeições naturais, embora não se pretendam rápidas nem transportáveis, como as do tipo fast food, estão no cardápio de muitos restaurantes que buscam alternativas de delivery para os clientes. Alimentos considerados do estilo natural também são comercializados em supermercados, com adaptações criativas em suas embalagens ecologicamente corretas. Segundo Garcia (2003), a valorização dos modos de fazer típicos, assim como a retomada de processos artesanais de preparação de certos produtos, não representa, necessariamente, uma volta às origens, mas um resgate do atributo tradicional como um bom argumento para venda. Os significados e sentidos atribuídos aos alimentos estão de acordo com cada contexto social, porque é regionalmente, em cada contexto, que se reconstroem a todo momento as regras de um jogo simbólico.

Uma culinária natural não se opõe rigidamente a adaptações de uma cozinha tradicional. A preparação de pratos típicos destinados à industrialização é ressignificada para o contexto, o que flexibiliza o sentido de tradicional. O simbolismo de tradicional, regional, caseiro e artesanal se reinterpreta de modo dinâmico nas trocas simbólicas. É na realidade de um contexto es- 
pecífico que as ideias de tradicional se fundem, ou não, com as de moderno, alcançando distinção social. Uma simples aparência de antigo e simples, de típico e regional pode atribuir prestígio a um alimento, ainda que a produção dele seja em larga escala e conte com as novas tecnologias. No naturismo, os alimentos estão sendo continuamente reinterpretados, reinventados, sendo alguns excluídos, outros reintroduzidos e outros ainda transformados, a fim de se adequarem às exigências da vida urbana e acelerada. $\mathrm{Na}$ bricolagem alimentar, um alimento desprezado em seu consumo cotidiano pode ganhar destaque em outro momento, e vice-versa.

O pão branco, segundo Montanari (2003), era um alimento de luxo, inacessível à maior parte da população na Idade Média; no século XIX, quando a farinha branca se popularizou, passou a alimento cotidiano e prestigiado como todos os produtos refinados. Hoje, o pão integral, típico no estilo natural, desprende-se de um significado grosseiro e pobre para o de um alimento tradicional e rústico, um pão original. Segundo Santos, num processo de reconstrução do gosto alimentar, que implica a construção de novas sensibilidades em relação ao comer, "o não consumo e/ou redução do consumo de carnes, em particular a carne vermelha, e do açúcar branco sempre foram atos simbólicos dos adeptos a uma alimentação natural" (2008, p. 168), mas

nada se tornou tão popular quanto o termo 'pão integral', simbólico para quem faz ou quer fazer dieta. Antes presente apenas em casas de produtos naturais, hoje ocupa espaços nas padarias e nas redes de supermercado, que compreenderam serem os alimentos naturais em geral uma importante fatia de mercado nas últimas décadas (2008, p. 277).

A reedição ou troca simbólica segue tendências modernas e ideais liberais numa concepção de liberdade banalizada associada à liberdade de consumo, em que "a liberdade do 
indivíduo é confundida com a liberdade para consumir" (p. 207), sustentando-se a crença de que, quanto mais opçôes para comprar, mais liberdade o consumidor terá para escolher. Desconstruindo essa crença, Fischler e Masson (2008) observaram - em estudo sobre a variedade de alimentos na França e nos Estados Unidos que, embora os americanos valorizem mais a liberdade de escolha do que os europeus e ofereçam um número maior de opções, não diversificam os alimentos de sua dieta tanto quanto os franceses.

Dar uma cara nova a um alimento velho pode ser uma estratégia de troca simbólica consciente e perversa quando submetida à lógica comercial, com interesses lucrativos, ainda que isso não seja consciente para parte dos agentes que operam essas trocas. No entanto, não é sempre com esses interesses que um alimento incorpora significados novos no estilo natural. Uma entrevistada que vendia pão integral caseiro sabia que, se produzisse em larga escala, poderia lucrar mais; mas isso não a motivava. Por esgotamento e cansaço - ela vendia bastante e não queria mudar a técnica de preparo, que a demandava demais por ser manual -, acabou encerrando sua produção natural. Para ela, o pão produzido em larga escala não era realmente natural.

Em nosso trabalho de campo, observamos que os entrevistados levavam uma vida bastante simples e se orgulhavam disso, o que lhes conferia distinção social. Os restaurantes que não expressavam interesses lucrativos eram prestigiados. $\mathrm{O}$ interesse lucrativo estava associado ao que a modernidade tem de pior e se distanciava de valores nobres, como a solidariedade e a fraternidade. Um casal que entrevistei disse ter saído da sociedade de um restaurante vegano porque estava em desacordo com sua busca por lucro, o que pervertia a culinária. Montou outro restaurante, em que podia reproduzir valores solidários e fraternos num clima mais cordial, próprio do estilo vegan.

Quando estive pesquisando num restaurante vegan em Botafogo, acabei atendendo aos comensais como garçonete, pois 
havia poucos funcionários no horário de pico do almoço. Ajudei a servir e arrumar as mesas, até como retribuição ao almoço que o proprietário gentilmente fazia questão que eu aceitasse, sem pagar. Observei que o tratamento que eu recebia quando reproduzia esse papel era diferenciado em relação às churrascarias. Quanto mais "habituê" do local, mais o comensal comungava princípios e me tratava como igual, sem atribuir um sentido de inferioridade à minha posição de atendente. Às vezes perguntavam sobre os alimentos e o que eu achava deles, travando conversas interessantes e produtivas de modo afetuoso. No entanto, outros comensais, que não costumavam frequentar o local e o visitavam para conhecer o tipo de comida, me dirigiam pedidos num tom solene de ordem, frio e objetivo, e nem sempre me olhavam no rosto ou usavam um simpático "por favor". Era como se eu fosse uma máquina de entrega de comida. Em determinada ocasião, uma colega nutricionista me reconheceu e, surpresa, me perguntou, sem constrangimento, o que eu estava fazendo de avental e se já tinha acabado o doutorado. A mesa ao lado, com clientes que me tratavam com indiferença e objetividade, se constrangeu e mudou a postura. Passou a me dirigir a palavra com respeito e a me perguntar sobre nutrientes, pedindo sugestôes para os males que andavam sentindo e até para os que achavam que iriam sentir, numa conversa animada, muito diferente da anterior, quando eu era somente uma garçonete.

A construção de uma hierarquia social é representativa de um habitus vegano, que, nesse exemplo, fica claro na diferença entre um tratamento mais humanizado e outro mais mecanizado. $\mathrm{O}$ estilo natural e vegano tem um projeto de mundo novo solidário, com relações sociais respeitosas e afetuosas, além de uma disposição para a cordialidade que contrasta com a postura individualista e impessoal do fast food. Os comensais se misturam nos restaurantes, mas o reconhecimento dos princípios do estilo natural se dá em função do jogo simbólico no campo. A identificação de uma conduta ou de uma comida como vegan depende do reconheci- 
mento de valores de distinção dos naturistas no campo, pois são estes que estão autorizados para essa legitimação.

Os princípios que norteiam o jogo simbólico, longe de estáticos, são cambiáveis, permeáveis a forças e pressões externas no campo da alimentação - atravessado, fragmentado e saturado de interesses. Fazendo-se uma correspondência com Bourdieu, o crítico de arte está autorizado a falar como julgador e tem a "satisfação de anunciar veredictos, de dizer o que é verdadeiramente o realismo, ou ainda, muito simplesmente, de decretar [...] quem é artista e quem o não é" (1989b, p. 293). A atribuição de alimentação natural não expressa princípios de percepção rígidos; apresenta-se mais flexível do que o vegan. Uma vegana critica a ausência de regras do natural, afirmando que todos podem ser naturistas; "só não se come cadeira". Para ser vegano, "tem que comungar o ideal, tem que dormir e acordar pensando nisso". Quando encontrei, ocasionalmente, um entrevistado vegano na padaria da esquina de seu restaurante comprando pão francês, ele se justificou dizendo que o pão era para os funcionários, reforçando as regras de que um vegano não se alimenta de pães que não sejam integrais.

É justamente nessa mistura de significados, tesouro de ideias, que se constrói uma prática de bricolagem alimentar no estilo natural ora mais, ora menos resistente à globalização, absorvendo o interesse econômico, mas não se reduzindo a ele, o que confere certa estabilidade social ao projeto naturista de um mundo novo natural. $\mathrm{O}$ naturista aposta numa Natureza ressacralizada, que reorganiza o jogo que o faz existir como tal. Nos termos de Bourdieu, "o jogo cria a illusio, o investimento no jogo do jogador avisado, dotado de sentido do jogo, que, habituado ao jogo, pois que é feito pelo jogo, joga o jogo e, por esse meio, o faz existir" (p. 286).

As regras que inserem os agentes nesse jogo são legitimadas no campo e tornam titubeantes e frágeis os discursos deles quando 
não estão orientadas por princípios de percepção específicos do campo, por agentes que não se apropriam dos signos ou que não reconhecem os encantos dos elementos míticos nas narrativas naturistas. A identificação e a delimitação de um campo etnográfico naturista demandam a incorporação desses princípios na experiência, na convivência com os estilos natural, vegan e vivo, para assim se poder "passar dos instrumentos utilizados pelo feiticeiro para o próprio feiticeiro, e deste para a crença dos seus clientes e, gradualmente, para todo o universo social no interior do qual se elabora e se exerce a magia" (p. 287). 